\title{
SUBJECTIVITY OF WOMEN'S BODY AS A RESISTANCE TO THE DOMINATION OF PATRIARCHY IN NOVEL VEGETARIAN BY HAN KANG
}

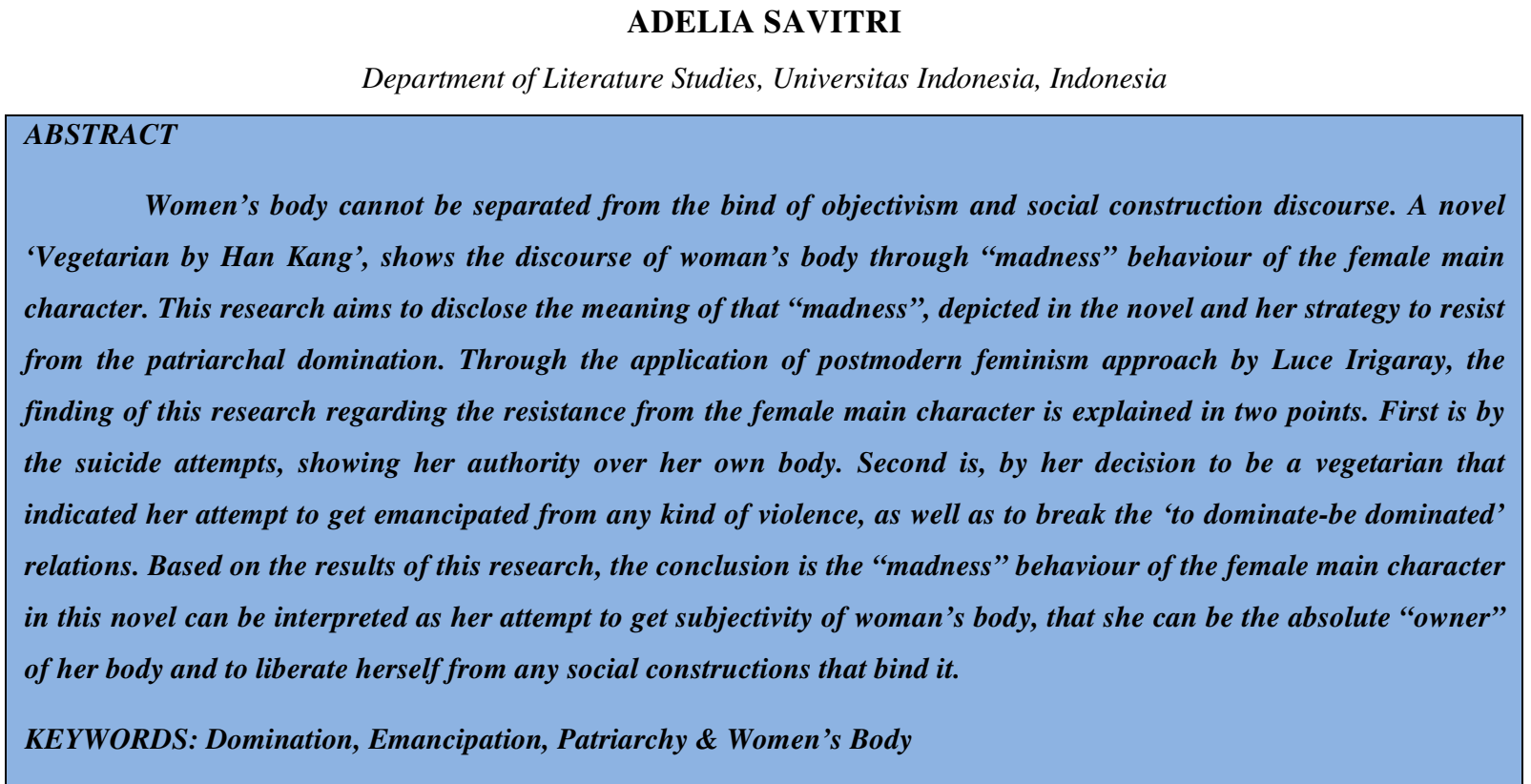

Received: Nov 20, 2017; Accepted: Dec 10, 2017; Published: Dec 20, 2017; Paper Id.: IJELFEB20181

\section{INTRODUCTION}

\section{Background of the Study}

Korean literature generally has a specific characteristic which different from other literatures in the world. The substance of literary work in Korean literature is more important than style of writing and aesthetic form. One of the unique characteristic in Korean literature that makes it special is an element from the concept of "Han" which related with Korean culture. "Han" can be defined as an element of suffering repeated until on the climax of sorrow. In the other hand, it describes the force to survive in that suffering. In period of Japan colonialism, Korean literature continually expressed the reality in Korean society. In the late 19th centuries and coming the 20th centuries, the form of aesthetic in Korean literature received many influence of Europe literature (Lee Tae-dong, 1996). The influence of Europe literature had been making innovation in Korean literature which was known had tendency to be realist. One of the Korean novels, which successfully step outside from the realist tendency and become an anomaly in Korean literature, is a novel 'Ch'aesikjuuija', by Han Kang which had been translated in English as 'Vegetarian'.

On May 16th, 2016, novel Vegetarian-in an English edition translation by Deborah Smith-got an award as a winner of Man Broker International Prize in category of the best novel translation by eliminatedmany

novelists in the world such as Orhan Pamuk, Kenzaburo Oe, and the other names. ${ }^{1}$ The title of Vegetarian

\footnotetext{
${ }^{1} \mathrm{http} / /$ themanbookprize.com/international/news/vegetarian-wins-man-brooker-international-prize-2016
} 
is not automatically telling us about only a vegetarian lifestyle, in contrast, it reflects about many problems of women violence.

Vegetarian narrates the story of the main character named Young Hye, who decided to be a vegetarian after she had nightmares. In her dream, Young Hye had some terror and walked away in the midst of the drop of blood, that derived from the meat which was hanged along in the darkened hallway. The nightmares continuously haunted Young Hye and made her became insomnia because, she felt fear if that nightmare could come back. In her dream, she saw the scene of assassination, but she did not know who was the killer and being killed. Young Hye's husband and her family, especially her father, assumed that her behaviour and her reason to become a vegetarian are irrational. Young Hye's decision to become a vegetarian is the beginning of conflicts, which 'open' the relation of female and male characters in this novel. This relation reflects the domination of men to women in it.

The novel is divided in three chapter and each chapter uses different point of view-Young Hye's husband, Young Hye's brother in law, and Young Hye's sister-to voice Young Hye's behaviour. As the main character, Young Hye is not given 'space' to voice her own perspective. Based on its structure, this novel emphasises in the domination to the female main character. The main character in this novel is a woman who is considered to be 'strange'-and even be mad-by her husband and some people around her. Young Hye's 'madness' can be seen from the way she treats her body start from when she decides to be a vegetarian until when she refuses to eat anything. However, that 'madness' behaviour lead to a strategy for achieving independence as a woman and liberate herself from men's domination.

The problem of this research is based on two cases. First, how does the form of the men characters domination to the main woman character in this novel? Second, how does the main woman character's strategy to liberateherself from the patriarchal domination? Based on those problems, this research applies postmodern feminism which was approached by Luce Irigaray.

\section{Research Methods}

This research used qualitative research approach, because the goal of this research is to interpret a novel. The primary source of this research is a novel entitled Vegetarian, written by Han Kang and translated in English by Deborah Smith. The novel that is used in this research is English translation by Deborah Smith. The novel consist of three chapter and 183 pages.

This research uses postmodern feminism theory which aims to discover the meaning behind the 'madness' of the main female character who desires to jump out from the patriarchy domination. Theory of postmodern feminism essentially wants to remove the binary opposition between masculine and feminine, sex and gender, men and women. The feminists postmodern found a way to break the conceptual limits that prevented women defined themselves through their own language (Gatens, 1992 and Tong, 2009). Irigaray offered a strategy for women to deconstruct metaphysical symbol which charged over their body by create their own 'language' (Irigaray, 1985 in Ida, 2015). Irigaray wishes that every woman will be able to liberate herself from the concept of feminine phallic to build the subjectivity of women's body (Tong, 2009, p. 296).

The concept of women's subjectivity which demonstrates the power over their body is used to reveal the meaning of the main woman character's behaviour in novel Vegetarian. However, before revealing the meaning of it, the domination of men characters which stimulates resistance attempt from the main woman character must be identified. 
Therefore,this research is done through two steps. The first step is identifying the forms of the patriarchy domination which did by the main woman character's husband and her father.

The second step is identifying the forms of the reciprocal which did by the main woman character. The forms of reciprocal can be found from investigating the main female character's ppeculiar actions from the focalization of her husband and her elder sister.

Through those steps, the strategy of the main woman character to step out from the patriarchy domination in this novel, can be revealed.

\section{RESULTS AND DISCUSSIONS}

This part consists of two parts. The first is analyzing domination of men objectification and violence to woman figure in novel. The second part is analyzing how the woman's body is used as resistance strategy to patriarchal domination.

\section{Domination of Men: Objectification and Violence to Woman in Novel Vegetarian}

Objectification can be defined from how men positioning and seeing women as an object. In other words, the subject who has authority to evaluate is a man. First chapter in this novel is opened by narration from Young Hye's husband. He describes about his impression to Young Hye in the first meeting and Young Hye is described as an ordinary woman.

Before my wife turned vegetarian, I'd always thought of her as completely unremarkable in every way. To be frank, the first time I meet her I wasn't even attracted to her. Middling height; bobbed hair neither long nor short; jaundiced, sickly-looking skin; somewhat prominent cheekbones; her timid, sallow aspect told me all I needed to know. $[\ldots]$

The passive personality of this woman in whom I could detect neither freshness nor charm, or anything especially refined, suited me down to the ground. There was no need to affect intellectual leanings in order to win her over, or to worry that she might be comparing me to the preening men who pose in fashion catalogues (Han Kang, 2017, p. 3).

Young Hye's husband in quotations above is giving objectification to Young Hye. It can be seen from his manner, to rate the types of women's body. Based on the quotations above, perception or ideal standard of women's beauty is measured by men. Women's body shapes and ideal face characteristic are always referred from men's judgement. In other words, women cannot define their own beauty standard.

However, despite Young Hye's body is not described as a kind ofbeautiful woman based on her husband's objectification, her eyelid and prominent cheekbones show 'originality' face of Korean women. If it is associated with the context of plastics surgery, which was increasingly attracted by women in Korea, it shows that Young Hye is not referring to the standard of Korean women's beauty which often performs plastic surgery, to enlarge their eyelids and pointed their cheek bones and jaws. Hence, Young Hye character's description was like, she maintains her body shape is an indication of Young Hye's independence in possessing her own body. The description indicates that she does not care with her appearance which isthe opposite of ideal standard of women's beauty in men's perspective. Nevertheless, it shows Young Hye's subjectivity does not stuck in construction of ideal body, which is formed and discoursed by domination of masculine appraisal. 
Furthermore, based on the dictions of Young Hye's husband, his appraisal reflects inferior judgment to Young Hye. His decision to marry Young Hye was precisely because of Young Hye's appearance, which demands him to do nothing extraordinary. In this case, the husband's character shows his objectification, by positioning his wife as an object and build hierarchy between them. He assumes as a subject that, his position is higher than his wife and he does not need to feel anxious of other men, as his competitors. Based on his appraisal, he thinks that, there is no man who is 'interested' in his wife. It shows that, there is hierarchical relation between figure of husband and Young Hye, as the result of the culture of patriarchy. This exposes that; appraisal of women is based on physical characteristics, without minding nonphysical things, such as personality of women.

Domination of men can also be found from the technique of narrative, which distinguishes 'voice'of husband character and 'voice'ofYoung Hye. Before Young Hye decides to become a vegetarian, the 'voice' of Young Hye is presented in the form of memories and cannot be heard by the husband figure.

The morning before I had the dream, I was mincing frozen meat-remember? You got angry.

“Damn it, what the hell are you doing squirming like that? You've never been squeamish before.'

If you knew how hard I've always worked to keep my nerves in check. Other people just get a bit flustered, but for me everything gets confused, speeds up. Quick, quicker.[...] My hand, the chopping board, the meat, and then the knife, slicing cold into my finger.[...]

Later that day, when you sat down to a meal of bulgogi, you spat out the second mouthful and picked out something glittering.

"What the hell is this?" you yelled. "A chip off the knife?"

I gaze vacantly at your distorted face as you raged.

“Just think what would have happened if I'd swallowed it! I was this close to dying!”(Han Kang, 2017, p. 19).

Quotations above show that the husband character often spells rude words and it makes Young Hye precisely easily makes mistakes. Expression of Young Hye's feeling, which is manifested in the conscience, shows the position of women as others, borrowing the term from Beauvoir, in its relatives with men. As a woman and a wife, the figure of Young Hye is not given broader space to voice loudly, to convey her point of view. In its relation with the husband character, women placed as 'the other' and their voices does not need to be heard by men. The relation of Young Hye and her husband can be seen that it still refersto the culture of patriarchy, when men is given greater space to voice and determine, while women have to voice something in limited space and placed as an object of determination. Thus, the domination of figure husband to Young Hye can be seen in the following quotation.

I sometimes told myself that, eventhough the woman I was living with was a little odd; nothing particularly bad would come of it. I thought I could get perfectly well, just thinking of her as a stranger, or no, as a sister, or even a maid, someone who puts food on the table and keeps the house in good order. But, it was no easy thing for a man in the prime of his life, for whom married life had always gone entirely without a hitch, to have his physical needs go unsatisfied for such a long period of time. So yes, one night when I returned home late [...] I grabbed hold of my wife and pushed her to the floor. Pinning down her struggling arms and tugging off her trousers, [...] She put up a surprisingly strong resistance and, spitting out vulgar curses all the while, it took me three attempts before I managed to insert myself successfully (Han 
Kang, 2017, p.30).

When Young Hye decides to become a vegetarian, she turns into a quiet figure and rarely speaks to her husband. She becomes cold and always ignores her husband's desire, to have sexual inter course as to Young Hye, her husband left the smell of meat which she hates the most. Young Hye's changes then considered as a peculiar act by her husband and because of it, she becomes like a stranger to her husband. However, in her husband's perspective, it does not impact something enormous since he only sees Young Hye as his maid. This confirms that the role of women only limited in domestic space. This is strengthen by the narration from her husband, which shows that, he considers his wife only as an assistant households and he still takes benefits from the role of women, eventhough her wife has the ability to liberate herself. The system of patriarchy says that men are those who have power and authorities. In other words, hierarchy is because the highest position is owned by men. This hierarchy is successfully separating two poles, namely the powerful and the weak. Men are considered stronger than women; therefore they are able to carry power. Hence, men get privileges as the subject.

The mention of 'sister' affirms that the power is owned by the husband figure. It also shows the boundary and hierarchy between their relations. Behaviour of Young Hye's husband, who obtrudes to his wife shows that, the domination of men produces violence against women. This refers to community system of patriarchy, which places women as the weak while men as the strong. Privileges of men as the subject build superiority over women. This reflects in previous excerpts, which show tha,t the husband character does not really care with Young Hye's refusal. However, as a man, actuallyhe does not want his superiority depraves because of it. Even though Young Hye has psychological reasons related to her peculiar behaviour, regarding the odour of meat, which can be smelled from her husband's body, her husband does not really want to understand it. Thus, figure of husband puts Young Hye as a sexual object with several domestic duties, not as a partner who has equal position.

The domination of men is not only shown through her husband's figure, but also her father. Young Hye's father is described as a man, who has abusive behaviour. It can be seen in the following quotation.

"What kind of talk is that?" my father-in-law yelled. "Grab her arms, quickly. You too, Mr. Cheong.”[...]

"Mm-mm... mm!"

My father-in-law mashed the pork to a pulp on my wife's lips as she struggled in agony. Though he parted her lips with his strong fingers, he could do nothing about her clenched teeth.

Eventually he flew into a passion again, and struck her in the face once more (Han Kang, 2017, p. 39—40).

The dialogue above is when the Young Hye's family hold gratitude banquet for her sister's new house. In that banquet, there are various menu of meat to serve. In Korean tradition, meat is a special menu (especially beef) to serve in every occasion (Latifah, 2017). By refusing to eat it, Young Hye is considered to not respecting the entire occasion. This sparks indignant of her father and causes her father's temper to do no good to Young Hye. As the head of the household, father's figure has 'superpower', since in the culture of patriarchy the absolute authority is given to the father. Patriarchy itself means 'power of father', as expressed by Rich (1976) in Bem (1993, p.40), "Patriarchy is the power of the: a familiar-social the fathers, ideological,... the female is everywhere subsumed under the male". Father's figure has the highest position and holds power, and even higher than Young Hye's husband. This can be noted that, Young Hye's husband is unable to defence that violence even with the law. 
The violence which done by Young Hye's father to Young Hye shows that, dominance of father is the absolute power to treat her daughter in all the way he wants. Actually, a few days before the banquet, Young Hye says that she turns to a vegetarian buther explanation is unacceptable and seems irrational to her father and her family. Opposition of Young Hye's choice considered her as 'the other' in her family because of her decision to be a vegetarian. It is reflecting how domination of the majority considers 'different' or 'strange' in addressing the minority, who have different perspective. Young Hye's decision to become a vegetarian inher family whotreasure to eat meat makes her as 'target' of violence. It started even since Young Hye's childhood and represents in quotation below.

Yeong-hye had been the only victim of their father's beatings. Such violence wouldn't have bothered their brother Yeong-ho so much, a boy who went around doling out his own rough justice to the village children. As the eldest daughter, In-hye had been the one who took over from their exhausted mother and made a broth for her father to wash the liquor down, and so he'd always taken a certain care in his dealings with her. Only Yeong-hye, docile and naive, had been unable to deflect their father's temper or put up any form of resistance. Instead, she had merely absorbed all her suffering inside her, deep into the marrow of her bones (Han Kang, 2017, p. 157).

The narrator of the past in the quotation above is In Hye who is Young Hye's eldest sister. When Young Hye eventually putted in an asylum because of her constant peculiar habit, In Hye reminds that Young Hye was her father's physical abusing target when she was a child. As a daughter, Young Hye receives stereotype as a weak woman and unable to defence the violence of his father. However, behind Young Hye's silence, it shows her power to survive on oppression, which continually comes from the domination of men, particularly her own father. In her adulthood, the experience of violence which she received from the past can be used as a base of the attempts of embodying her 'strange' behaviours. Furthermore, violence which she receives comes from no other men, but the closest men of her. The oppression of the men by the main woman character emerges her, to liberate herself from the dominance of men through subjectivity of her body.

\section{Women's Body as Resistance Strategy to Patriarchal Domination}

As what is explained earlier, subjectivity of a woman's body is the ability of a woman to release her own self from the form of stereotype based on the domination of men. Women's subjectivity in postmodern feminist concept can be built from their bodies. The women can escape from their limitation, if they position themselves as a subject with their bodies. According to Irigaray, the essential femininity had been repressed by patriarchy culture. Therefore, the femininity is valued by masculine's parameter (Weedon, 1987 in Fitria, 2009, p. 17).

Women become the subject of autonomous toward her own self entirely. The subjectivity toward women's body represents by the figure of Young Hye, in the beginning of the story as these following quotations.

The only respect in which my wife was at all unusual was that she didn't like wearing a bra. [...] I couldn't get my head around it. Eventhough she had shapely breasts, which might suit the 'no-bra look'. I would have preferred her to go around wearing one that was thickly padded, so that I could save face in front of my acquaintances.

Even in the summer, when I managed to persuade her to wear one for a while, she'd have it unlooked barely a minute after leaving the house. The undone hook would be clearly visible under her thin, light-coloured tops, but she wasn't remotely concerned (Han Kang, 2017, p. 5-6).

Women's bra, which uses to protect the breast, is considered as something uncomfortable to Young Hye. Whereas, her husband feels more proud if his wife has larger breast. Therefore, he expects his wife to wear bra with thicker 
sponges. This shows that, the function of bra is not only to cover the breast, but also uses to build women's femininity, which refers to men's sexuality. Thus, bra can be seen as a metaphore of the body curb of women which embedded with the construction of femininity based on men's sexuality. Through her refusal of wearing bra, the main woman character in this novel shows her decision to become the autonomous human. She tries to break free from shackles of men's sexuality, which she thinks is cuffing women.

Young Hye's resistance also can be found in a family banquet, while her father forces her to swallow cuts of meat after he slaps her cheek.

'... get away!'

At first, she drew up her shoulders and seemed about to flee in the direction of the front door, but then she turned back and picked up the fruit knife that had been lying on the dining table. [...]

Jaw clenched, her intent stare facing each one of us down in turn, my wife brandished the knife.

'Stop her...'

'Stay back!'

Blood rib boned out of her wrist. The shock of red splashed over white china. As her knees buckled and she crumpled to the floor (Han Kang, 2017, p.40-41).

After receive violent behaviour of her father, Young Hye leaves the house. However, based on text above she turns back to take a knife and attempt suicide. It can be seen as Young Hye's effort to show her power over her own body. In this case, her body is a media to fight over oppression, which she received previously. It proves that, her subjectivity is a defence of a woman who previously dominated. By scratching her wrist with a knife, she indirectly 'intimidates'men, who are often violence to her. The abnormal label which embedded her, because of her decision to become a vegetarian is opposed by Young Hye, through her suicide attempt. It means that Young Hye tries to reveal that, she has the entire right of her own body. She also tries to destruct ideology of patriarchy which binds her and put her onto marginal position. How Young Hye turns to become a vegetarian and her main reason to insist, is shown in these quotes.

My wrist is okay. It doesn't bother me. The thing that hurts is my chest. Something is stuck in my solar plexus. I don't know what it might be. It's lodged there permanently these days. [...]

Yells and howls, threaded together layer upon layer, are enmeshed to form that lump. Because of meat. I ate too much meat. The lives of the animals I ate, have all lodged there. Blood and flesh, all those butchered bodies are scattered in every nook and cranny, and though the physical remnants were excreted, their lives still stick stubbornly to my insides (Han Kang, 2017, p.49).

Those quotations are the voice of Young Hye, which expresses her main reason to become a vegetarian. Young Hye's expression that, something lives in her diaphragm can be understood as a critic, from a vegetarian's perspective over the violence, which was performed by human to other creatures, such as animal for the sake of survival. Human depends and needs the lives of other living creatures, to support the sustainability of their lives. This critic is photographing the side of 'predators' in human's life, which symbolises the 'cruelty' in life. With her choice to become a vegetarian, Young Hye tries to free herself from the side of 'predators' that, she feels in her body and want to release herself from the violence of human to another human being, or human to other living creatures. Even though being a vegetarian, it causes Young Hye 
to exile by her family and those who are around her, she insists on her own choice, which makes her as an autonomous woman, who does not need to depend on anybody. Therefore, her decision to become a vegetarian can be understood as her effort to exempt from all forms of violence, as well as to destruct the chain of dominated and being dominated circle. With that reason, in extreme act, Young Hye's behaviour shows the symptoms of her rejection to any kind of food and then, she decides to consider herself as a tree.

'I didn't, you see. I thought trees stood up straight... I only found out just now. They actually stand by with both arms in the earth, all of them. Look, look over there, aren't you surprised?' Young Hye sprang up and pointed to the window. 'All of them, they're all standing on their heads. [...]

'Do you know how I found out? Well, I was in a dream, and I was standing on my head... leaves were growing from my body, and roots were sprouting from my hands... so I dug down into the earth. On and on... I wanted flowers to bloom from my crotch so I spread my legs; I spread them wide...' [...]

'I need to water my body. I don't need this kind of food, sister. I need water.' [...]

'I don't need eat, not now. I can live without it. All I need is sunlight.'

'What are you talking about? Do you really think you've turned into a tree? How could a plant talk? How can you think these things?' [...]

'You're right. Soon now, words and thoughts will all disappear. Soon.'(Han Kang, 2017, p. 148-154).

Young Hye is eventually taken to asylum, since her thought cannot be perceived by people around her. Young Hye's position in asylum is strengthening her position as 'the other': a woman who is ousted because of different standardisation of normality, from majority's perspective. An expression which considers her body as a tree cannot be simply viewed as her peculiar action, but far more than it is the meaning, which associates subjectivity from a woman's body. Young Hye desires to become a tree and chooses not to live as; either animal or human is because, both of them are having sides to dominate and being dominated. Moreover, to Young Hye, both of animal and human have the side of 'beast', which sparks behavioural violence, in relation to dominate and being dominated. In contrast, a tree is a source of life, since it produces oxygen for living creatures.

Furthermore, Young Hye's decision to cogitate herself as a tree can be seen as an effort to be free from dominance, which oppressed her. The oppressions which came from the domination of men: from her husband and her father, can be seen as a metaphor that, human and animal have 'desire of predators' and often, perform violence. With that reason, Young Hye tries to escape from the domination of them; even though it may lead her to death, since she refuses to eat any meals. As it is known as the subjectivity of her, Young Hye proves that, she has the power over herself and tries to reach her freedom. Asylum has become a place for Young Hye to find her subjectivity and to liberate as well as escaping any 'normal' choices. For Young Hye, return and continue her previous normal live means, she will be back to enter the world, which is dominated by the culture of patriarchy and will 'bother' her 'madness'. That 'madness' to consider herself as a tree, at the end of the story it can be understood as her effort to resist and liberate herself over shackles of patriarchy construction that seize her 'voice'. This also shows the freedom of a woman, to master her own self and release all of her social norm entanglement.

\section{CONCLUSIONS}


'Vegetarian' novel by Han Kang, presents the effort of a woman to be free from the chains of patriarchy domination. The main woman character in this novel, often receives violence from her husband and her father. This can be seen as the result of patriarchy, which gives absolute power to the men. Young Hye, the main woman character in this novel tries to oppose the dominant construction towards women's body, which says that a woman's body is considered as an object.

The main woman character's resistance, through her body is shown through several actions. The first is from her effort to attempt suicide and it shows that, she has the absolute right over her own body. The second is, from her decision to become a vegetarian and it can be interpreted as her effort to release herself from every form of violence, from the domination of men and also, to break the chain of dominated and being dominated relation. The third is, through her consideration to appraise herself as a tree, which can be known as an effort to liberate her and jump out from oppressions which dominated her.

Young Hye's 'madness' behavior to consider herself as a tree at the end of the story can be understood as, her effort to resist and liberate herself over shackles of patriarchy construction, that seize her 'voice'. This also shows the freedom of a woman, to master her own self and release all of social norm entanglement.

\section{REFERENCES}

1. Bem, Sandra Lipsitz. (1993). The Lenses of Gender. London: Yale University Press.

2. FitriaMayasari. (2009). Subje ktivitas Tubuhperempuandalam Meresistensi Ideologi Patriarki (sebuah Kajian Berperspektif Feministerhadap Novel “The Bell Jar” karya Sylvia Plath).Tesis S2 Prodi Ilmu Susastra Fakultas Ilmu Budaya Universitas Indonesia.

3. Gatens, Moira. (1992). Power, Bodies and Difference. Dalam Michèle Barrett dan Anne Phillips, ed. Destabilizing Theory : Contemporary Feminist Debates, hlm. 120 - 135. California : Stanford University Press.

4. V. Jaisre, The Paradigmatic Shift: From Subordination to Emancipation in Rajam Krishan Lamps in the Whirlpool, International Journal of English and Literature (IJEL), Volume 5, Issue 5, September - October 2015, pp. 85-90

5. Han Kang. (2017). Vegetarian. Tangerang: Baca.

6. Ida Nurul Chasanah. (2015). Politik Tubuhdalam Karya - Karya Perempuan Pengarang Indonesia Era Reformasi. Disertasi S3 Prodi Ilmu Sosial Fakultas Ilmu Sosialdan Ilmu Politik Universitas Airlangga

7. Lee Tae-dong.(1996). Korean Literature Today.Seoul: The Korean Culture and Arts Foundation.

8. Tong, Rosemarie Putnam. (2009). Feminist Thought: A More ComprehensiveIntroduction. Edisiketiga. Colorado: Westview Press 
